\title{
TOURISM IN CAVES AND THE CONSERVATION OF THE SPELEOLOGICAL HERITAGE: THE CASE OF SERRA DA BODOQUENA (MATO GROSSO DO SUL STATE, BRAZIL)
}

\author{
JAMSKI TURIZEM IN OHRANJANJE SPELEOLOŠKE DEDIŠČINE: \\ PRIMER IZ SERRA DA BODOQUENA (MATO GROSSO DO SUL, \\ BRAZILIJA)
}

\author{
Heros Augusto Santos $\mathrm{LOBO}^{1,2} \&$ Edvaldo Cesar MORETTI ${ }^{2}$
}

\begin{abstract}
UDC 551.44:338.48(81)

Heros Augusto Santos Lobo \& Edvaldo Cesar Moretti: Tourism in Caves and the Conservation of the Speleological Heritage: The case of Serra da Bodoquena (Mato Grosso do Sul State, Brazil)

The Serra da Bodoquena is the region in the state of Mato Grosso do Sul, Brazil in which the municipality of Bonito is located. This municipality is the primary calling card for tourism in the state and is one of the most developed areas of ecotourism and speleotourism in the country. The tourism there is entitled ecotourism, and is designed to be sustainable. The present case study focuses on the ecologically sustainable aspects of the speleotourism practiced there, especially the proposals for tourist carrying capacity adopted. The results and discussion provide suggestions for the adoption of a different formulation of carrying capacity focusing on both operational and quantitative aspects. Ecologically sustainable speleotourism in the Serra da Bodoquena should be possible as long as new proposals limiting visitation are adopted which conform to technical environmental management procedures and consider the interests of local stakeholders.
\end{abstract}

Keywords: ecotourism, speleotourism, carrying capacity, management.
Izvleček

UDK 551.44:338.48(81)

Heros Augusto Santos Lobo \& Edvaldo Cesar Moretti: Jamski turizem in ohranjanje speleološke dediščine: primer iz Serra da Bodoquena (Mato Grosso do Sul, Brazilija)

Mesto Bonito leži v regiji Serra da Bodoquena, v brazilski državi Mato Grosso do Sul. Ta mestna regija je adut za turizem $\mathrm{v}$ državi in najprimernejše področje za razvoj jamskega turizma. Kot turizem se razume "ekoturizem « in je načrtovan kot »trajnostni«. Študija je osredotočena na ekološko trajnostne vidike tamkajšnjega jamskega turizma, še posebej na turistične kapacitete oziroma predlagane omejitve. Prispevek priporoča različne pristope za ugotavljanje nosilnih kapacitet s poudarkom tako na izvedbenih kot tudi na količinskih vidikih. V Bonitu je ekološko trajnostni jamski turizem mogoč, a le če bodo sprejeti predlogi o omejitvi obiska $\mathrm{v}$ skladu s tehničnimi in okoljskimi pristopi ter upoštevani interesi lokalnega prebivalstva.

Ključne besede: ekološki turizem, jamski turizem, samočistilna sposobnost, upravljanje.

\section{INTRODUCTION}

Tourism is one of the main economic activities of the area of the Serra da Bodoquena in the state of Mato Grosso do Sul in Brazil, where the municipality of Bonito is located. It is an area blessed with the unique natural beauty of karst areas, and is one of the most important karst areas in the country. Some characteristics of its landscapes are the rivers with crystal clear water and waterfalls which are in a constant state of change due to the process of

\footnotetext{
${ }^{1}$ Postgraduate Program in Geosciences and the Environment - São Paulo State University (UNESP), Rio Claro, Brazil. e-mail: heroslobo@hotmail.com 2 - Research Group of Territory and the Environment - Dourados Area Federal University (UFGD), Dourados, Brazil. e-mail: ecmoretti@hotmail.com
}

Received/Prejeto: 19.05.2009 
deposition and dissolution, as well as steeply cut canyons and nearly 200 caves already identified. This landscape provides the greatest local attractions for tourism and makes various recreational uses of the land possible for tourists with a variety of profiles.

Tourism in the Serra da Bodoquena is concentrated in three municipalities: Jardim, Bodoquena and Bonito, with the latter having been the first to develop such activities in the region. All three of the municipalities have a typically rural profile, with a more tranquil style of life than is found in most of the big cities of the country. The region is known both nationally and internationally as a pole for sustainable ecotourism.

The present article focuses on the caves exploited for tourism in the Serra da Bodoquena. Given their inherent fragility, they require special care to guarantee preservation.

Tourism in caves, or speleotourism as it is called in Brazil, is a recent area evolving in the spectrum of possibilities for tourism in natural areas. On the international level, the study of Cigna and Burri (2000) is the most complete for this kind of tourism. It presents the economic characteristics and issues related to the planning and management of caves. Other papers worthy of note include that of Doorne (2000), which investigates the social carrying capacity during the management of tourist caves, that of Cigna and Forti (1988) presenting a proposal for the development of a management plan for a cave, and that of Hoyos et al. (1998) expressing concern with the limits of sustainability in the exploitation of the underground environment.
In Brazil, nearly 200 caves are subjected to some type of tourist visitation (Lobo et al. 2008), although this number may actually be much larger. Various articles with different focuses on speleotourism have already been written in the country, especially the descriptive analyses of Figueiredo (1998) and Marra (2001), as well as studies focused on the environmental impacts of tourism in caves of Scaleante (2003), Verissimo et al. (2005), and Lobo (2006a), and others focused on the tourist carrying capacity such as that of Boggiani et al. (2007a) and Lobo (2008). Few of these, however, have focused on this topic in the Serra da Bodoquena. The most relevant are those of Lino et al. (1984), which provides a general description of the natural caves to be exploited by ecotourism in the region; Labegallini (1996), with a proposal for tourist structure of minimal impact for the Lago Azul cave; and Boggiani et al. (2007a), with a study of the environmental impacts on a protected natural area, the Natural Monument of the Lago Azul, which includes the cave of the same name and that of Nossa Senhora Aparecida.

In general, these articles provide solutions for specific caves. The present paper, however, presents a wider view of the general context for the utilization of caves for tourism in the region, in an attempt to identify how technical procedures of management and the characteristics of caves can contribute to an increase in the ecological sustainability of tourism in the region. More specifically, this article analyzes the tourist use of caves, in keeping with a discussion of the ideals and practices of ecotourism, carrying capacity and sustainable tourism in the region.

\section{METHODS AND STAGES OF RESEARCH}

After a review of the literature providing a panorama of speleotourism in Brazil, as well as the development of the evolution of tourism in the Serra da Bodoquena, field visits were made to all of the caves directly related to tourism: Lago Azul, Sao Miguel, Mimoso, Ceita Corê and the
Anhumas pit, all in Bonito, as well as the Araras pit and the Mysterious lake in Jardim and the Urubu-Rei cave in Bodoquena. A decision was made to focus only on those where tourism is actually being developed (Figs. 1 and 2; Tab. 1), since many of these attractions have been closed

Tab. 1: Tourist caves in the Serra da Bodoquena.

\begin{tabular}{|l|l|l|l|l|l|}
\hline Cave & District & Conservation Status & Official Tourist Opening & Owner & Carrying Capacity Criteria \\
\hline Anhumas pit & Bonito & RPPN & 1996 & Private & Operational \\
\hline Araras pit & Jardim & RPPN & 1996 & Private & Operational \\
\hline Lago Azul cave & Bonito & MN; PN & 1992 & Public & Environmental \\
\hline Sao Miguel cave & Bonito & - & 1999 & Private & Operational \\
\hline RPPN - Private Natural Heritage Reserve; MN - Natural Monument; PN - National Heritage. \\
\hline
\end{tabular}




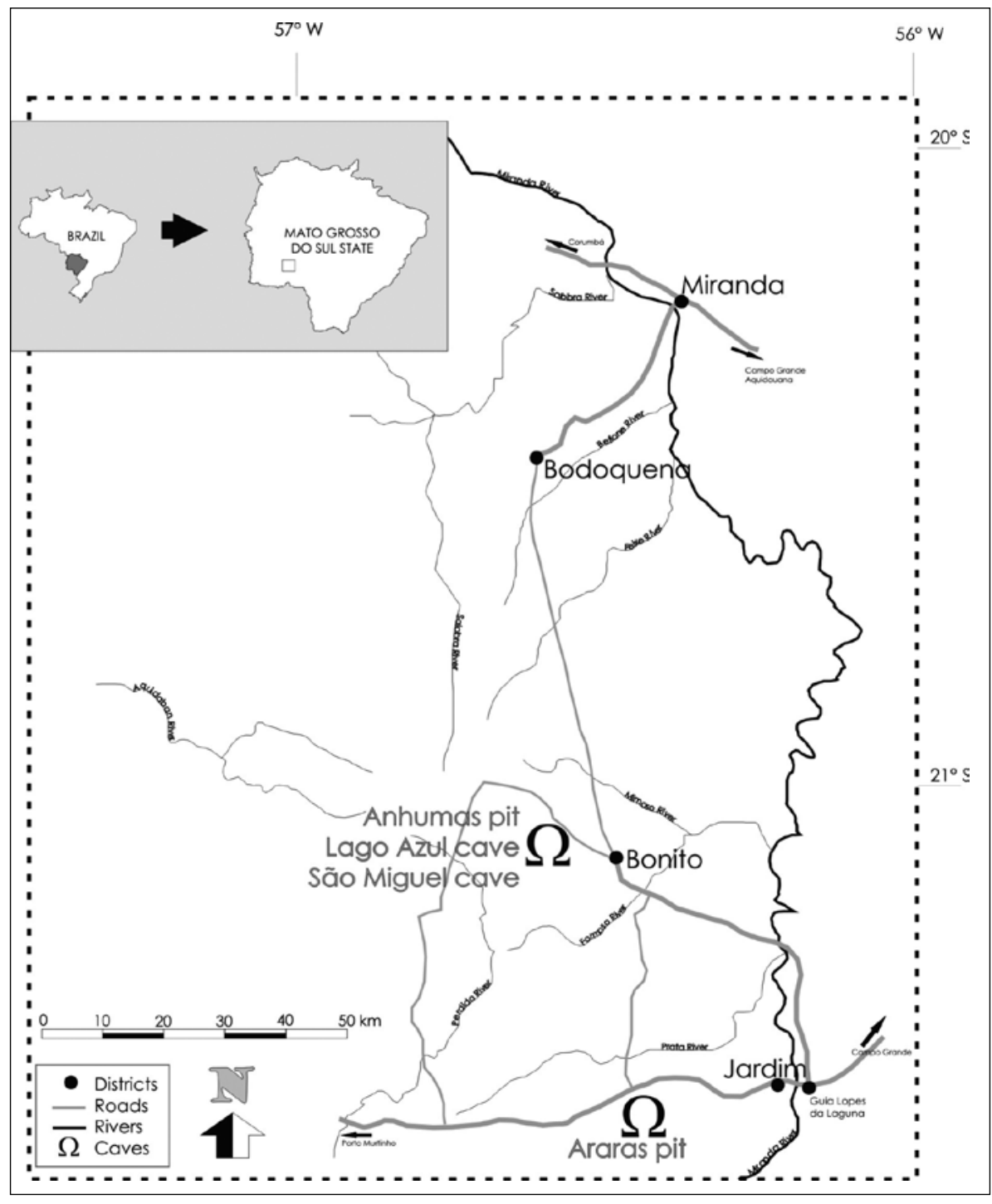

For this reason, as well as the consideration of other legal aspects, these locations have been closed by the environmental authorities.

The caves were amply documented with photographs, and observations made about access structures, as well as a study of the documents which orient the management plan of each of them. The data and information collected were analyzed from technological-methodological and theoretical/conceptual points of view, on the basis of the work of Cigna and Forti (1988), CifuentesArias et al. (1999), McCool and Lime (2001), Swarbrooke (2000), Lobo (2006a) and Boggiani et al. (2007a). The

Fig. 1: Map showing location of the caves studied. Modified from Gnaspini et al. (1984) and Lobo (2006b). due to a lack: a) environmental licensing; and b) management plan for tourist use. Many of the caves which were closed to visitation had actually constructed access structures and made other alterations, although these were implemented without any study of possible impacts. analysis gave rise to the formulation of proposals which suggest intervention in relation to technical and conceptual aspects of the ecological dimension of speleotourism in the region, with implications for economic and social dimensions.

\section{TOURISM IN THE SERRA DA BODOQUENA}

The municipality of Bonito, first to develop tourism in the Serra da Bodoquena, is a city in which the economy was previously based primarily on farming. Until the 1970's, the present tourist sites were utilized only for the leisure of the local inhabitants, and were little known outside the immediate region. The activities consisted primarily of bathing in rivers and waterfalls and fishing, with the permission of the rural owners (Barbosa \& Zamboni 2000; Vargas 2001).

The growth of tourism in Bonito has been due to two main factors: 1) the offering in 1992 and 1993 of the first training program for tourist guides, conducted with 

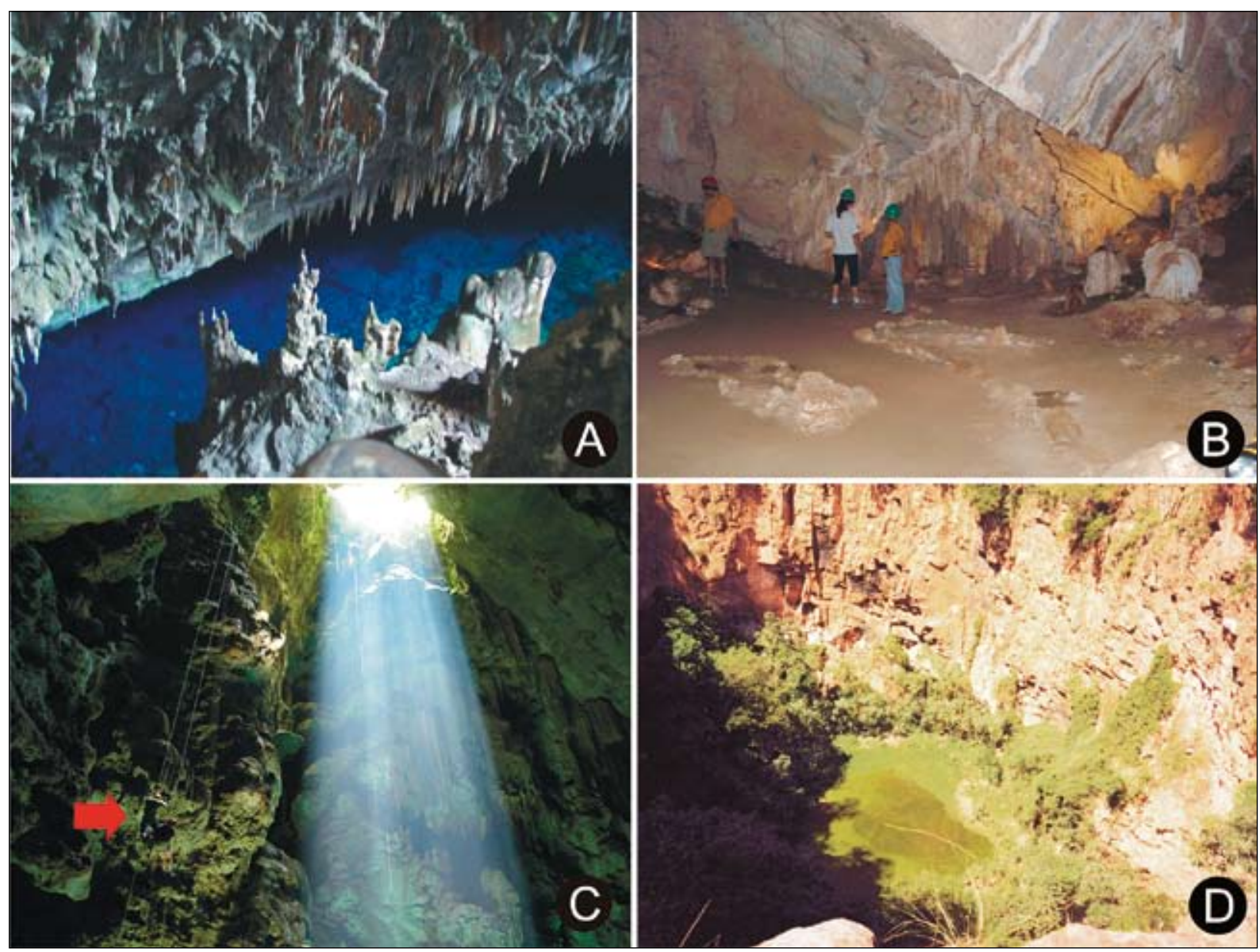

Fig. 2: Views of caves studied in the present article: A -View of the blue lake in the Lago Azul cave; B - Tourists in the São Miguel cave, the only one in the Serra da Bodoquena with interior artificial lighting; $C$ - Tourists (red arrow) rappelling down into the Anhumas pit; $D$-View looking down into the Araras pit. At present, some 80 pairs of two different species of parrot make their nests in the walls of the pit; various toucan and other birds are also found in the area (Photos A, B and D: H. Lobo; Photo C: A. S. Amorim).

the support of local stakeholders and universities to meet the needs of the growing demand of local tourism; 2 ) the Franco-Brazilian expedition to the area in 1992 (Boggiani 2001). This expedition was responsible for the underwater exploration of the Lago Azul cave, which led to paleontological discoveries and images aired on national [international?] television. The rising interest in the area led to a concern with the need to limit visitation of the natural attractions in order to diminish degradation and increase the safety of tourists.

The increase in tourist activity associated with this local situation is part of the process of the valuation of nature, a mark of modern society in the twentieth century and the beginning of the twenty-first century. Tourism is one of the ways that nature can be incorporated as part of the capital of a region, with those locations with attractive natural landscapes being attributed greater value.
Serra da Bodoquena is promoted by the local stakeholders as a sustainable ecotourist destination, and the municipality of Bonito has received a variety of prizes for being the best sustainable tourist destination in the country. That which is emphasized is the concern of the municipality with the environment. One aspect is the fact that the attractions are managed by the local population, since few are located in public areas. The owners of the attractions are aware of the fact that nature is what they have to sell, and this has led them to take great care in its conservation. However, the greater emphasis given to these prizes is their market appeal.

At present, Bonito has a Municipal Council for Tourism (COMTUR), composed of the main stakeholders of local tourism: members of the government and private enterprise, as well as non-governmental organizations involved in the preservation of the environment. It also has associations which attempt to represent the 
interests of the local actors, including tourist guides and agencies, owners of the attractions, and businessmen. The municipalities of Jardim and Bodoquena have a political-institutional structure and a tourist infra-structure which is inferior to what is found in Bonito, possibly because fewer attractions have been opened to the public.

One of the positive aspects identified by various studies (e.g. Lunas 2000; Grechi et al. 2009) is the use of the system of vouchers to control the number of visitors in the municipality of Bonito. This system makes it possible to impose limits on the visitation for each of the attractions, thus avoiding a constant excess in visitation and the damage this can cause to the environment. Grechi et al. (2009) explain that these vouchers were originally designed by the owners of the attractions, although they were later adopted by the municipal government via the local COMTUR. Lunas (2006) suggests that the visitation limits are not the main objective of the system, but rather control for tax purposes. In most cases, visits are limited as a function of the operational carrying capacity of the attraction.

Officially, speleotourism in the Serra da Bodoquena is limited to four caves. By far the best known is that of Lago Azul, and this has been visited for some time. Lino et al. (1984) report that this cave was discovered in the mid-forties by the then owner, with its visitation beginning in the mid-seventies based on the initiatives of local inhabitants. The cave was designated a national heritage site in 1978 by the Brazilian National Institute for the preservation of the Artistic and Historic Heritage (IPH$\mathrm{AN}$ ), justified by the exceptional scenic value and scientific value offered by the location. Later, in 2007, was placed in the list of geological sites in Brazil (Boggiani et al. 2007b), with the potential to be raised to world speleological heritage, cause it has the exceptional features of the landscape and established conservation guidelines, as described by Hamilton-Smith (2007).

In 1982 the area housing this cave, as well as that of Nossa Senhora Aparecida, which was visited in an unorganized manner, was acquired by the government. Since 1993, access to the Lago Azul is only permitted to people accompanied by tourist guides. In 2001, the caves and the surrounding area became a Conservation Unit for Full Protection ${ }^{1}$ (Mato Grosso do Sul 2001).

Most of the recommendations for the management of the caves arising from scientific studies have not yet

\footnotetext{
${ }^{1}$ In Brazil, protected natural areas are regulated by a federal law, the National System of Conservation Units. These units are separated into two categories, those awarded Full Protection, where only indirect use of the natural resources is permitted, such as is the case of tourism, and those for which Sustainable Use is permitted, where the restrictions for anthropic use are much more flexible.
}

been implanted, such as carrying capacity and the monitoring of impact (Boggiani et al. 2007a), as well as the implantation of a circular path for visitation originally proposed by Lino et al. (1984) and Labegalini (1996).

The second speleotourist attraction to be addressed is the São Miguel cave. Located on private property (São Miguel Farm), it has received visitors since 1999; these visits are always accompanied by tourist guides and obey the limits set by the Management Plan: 285 people per day in the summer and 255 in the winter, in groups of up to 12 people. These values are based on the management capacity installed at the attraction, with no direct mention of environmental parameters. The reduction of the limit in winter is due to the shorter period of daylight hours, since the contemplation of the surrounding area, which constitutes part of the official activity, is only possible during daylight.

São Miguel cave was equipped for visitation with the installation of a swinging bridge to provide external access, the construction of internal metallic and wooden steps, and the provision of compact fluorescent lights. The cave is equipped with first aid kits and litters to be used in the case of emergencies. After the visit to the cave, tourists are returned to the reception area via electric train. On rainy days, umbrellas are provided for the external trail, a legal requirement to allow visitation on such days.

The third cave, the Anhumas pit, is a commercial phenomenon for local tourism. Despite the extremely high entrance fees charged in relation to Brazilian wages this attraction is one of the most sought after in the region, even though tourism in the area has generally decreased. Discovered in 1979, this pit was visited for the first time in 1984. The part of the cave submerged in the lake is some 80 meters deep, and added to the 72 meters descended by rappel from the entrance to the surface of the lake, provides a total vertical development of 152 meters. Tourist visits, initiated by cave divers and the highly adventurous in 1996, have intensified since the official opening of the pit as a tourist attraction in 1999. The daily limit is 18 visitors - again not based on environmental parameters - and is divided into two sessions. Safety is one of the main emphases in the exploitation of the Anhumas pit, and on the day prior to the visit, all those participating in the visit must undergo a training program to verify their physical and psychological conditions. The entire 56 hectare area surrounding the cave is in the process of being established as a RPPN, a special kind of Unit of Conservation of private domain designed for sustainable use.

The final cave to be discussed here is that of the Araras pit, which has been discovered in 1912. It is one of the largest cave skylights in the world, approximately 500 
meters around and 124 meters deep. During the sixties and seventies, it was used as a cemetery for the cars of people who had been murdered in conflicts over land, and in 1967, the army used the skylight to train the techniques of rappelling.

Tourism has been a boon to the preservation of the environment of the Araras pit. A report in 1996 affirmed that no parrots were to be found in the location (Ribeiro 1996), but nowadays some 80 pairs of two different species of parrot make their nests there, as well as various toucans and other birds. The work of conservation, in conjunction with tourism and the environmental education developed along the trail of approximately 950 meters which goes around the pit, have contributed to the improvement in the conditions for wildlife. The entire 25 hectares of the area around the pit have recently been transformed into an RPPN, and visitation must be accompanied by the presence of a guide, who helps to develop environmental awareness as he helps tourists interpret what is seen.

Other possibilities in addition to these four caves also exist for speleological development in the Serra da
Bodoquena. Studies such as that of Camargo and Lourenção (2007) point out the existence of more than 170 known caves in the region. Some of these have been used as tourist attractions in the past, although no management studies were conducted, and they were later closed by the government; others are visited sporadically. Lobo (2007) has emphasized the tourist potential of four specific caves in the National Park of the Serra da Bodoquena, another Unit of Conservation in the area not yet open for visitation by the general public.

Another modality related to the caves which has great potential for tourism in the area is cave diving, since many of the caves in the Serra da Bodoquena region are flooded. The underwater visibility is fantastic, and various curiosities have been revealed. Many of these flooded caves are ideal for contemplative or adventure diving, as well as for snorkeling. Recent studies have advocated the official opening of two of these flooded caves for cave diving: Mysterious lake and the Hole of the Bees. This would introduce new possibilities for use of the local speleological heritage (Barroco Neto 2009).

\section{ECONOMIC IMPORTANCE OF SPELEOTOURISM IN THE REGIONAL CONTEXT}

In general, there are many speleological attractions in the area of the Serra da Bodoquena which can attract tourists with various socioeconomic profiles. The entrance fees charged for the summer season of 2006/2007 varied from US\$ 12 in the Lago Azul cave and the Araras pit and the US\$ 15 for the São Miguel cave to the US\$ 160 charged to visit the Anhumas pit (US\$ 230 with snorkeling). In contrast to the prices of the other attractions in the area, these do not fluctuate with the season. Table 2 presents the total number of visitors for each of the official speleologic attractions for the years between 2001 and 2005.

These data show that the Serra da Bodoquena has a reasonable potential for speleotourism. Although the

Tab. 2: Numbers for speleotourism in the Serra da Bodoquena.

\begin{tabular}{|l|c|c|c|c|c|}
\hline \multirow{2}{*}{ Cave } & \multicolumn{5}{|c|}{ Total number of visitors } \\
\cline { 2 - 6 } & 2001 & 2002 & 2003 & 2004 & 2005 \\
\hline Lago Azul cave & 46.056 & 51.078 & 48.364 & 44.014 & 45.116 \\
\hline São Miguel cave & 6.432 & 8.847 & 11.894 & 8.950 & 5.756 \\
\hline Anhumas pit & 1.235 & 751 & 738 & 909 & 720 \\
\hline Araras pit & - & - & 1.272 & 3.260 & 3.327 \\
\hline
\end{tabular}

Source of information: Lobo (2006b). numbers are small in relation to international standards (cf. Cigna \& Burri 2000), they are relatively large in relation to the standards of ecotourism in Brazil. The fluctuation observed in total number of visitors to the São Miguel cave and the Araras pit could not be identified, although they were interpreted by their owners as a question of specific marketing strategies and variation in the profile of the tourists visiting the region.

Considering the average number of arrivals in the region, estimated by the Association for Tourist Attractions in Bonito and Region (ATRATUR) to be some 70,000 tourists per year, some $65 \%$ of them visit the Lago Azul cave. Based on the prices practiced in 2005, speleological attractions are responsible for the sum total of US\$ 778,846.00 (seven hundred seventy eight thousand, eight hundred and forty six dollars) a year. Moreover, this includes only those tourists who arrived on the basis of the unified voucher system practiced in Bonito and controlled by the Secretary of Tourism of the municipality. 
In the case of the Araras pit, many tourists arrive from the neighboring municipality of Jardim and do not use the system, so the flow of tourists may be even greater. Nor do these figures take into consideration the indirect expenditure of the tourists who come to see these attractions, such as food and lodging, nighttime entertainment, transportation, and the purchase of souvenirs and other items in the shops.

On the other hand, it is important to point out that most of the capital generated by tourism in the region is concentrated in the hands of the owners of the attractions. Only a small portion, in the neighborhood of $15-$ $20 \%$, is left to be shared by the municipal government, tourist guides, agencies, transport companies, etc. This division is regulated by COMTUR. Despite the disparity in the division of the resources, Lunas (2006) points out that tourism in nature generates approximately $1,100 \mathrm{di}$ rect jobs in Bonito alone, which corresponds to approximately $6.2 \%$ of the inhabitants of the municipality and $14 \%$ of the economically active population. The studies of Lomba (2004) reinforce this conclusion; he points out that the area occupied by agriculture in the region decreased $75 \%$ between 1986 and 2002. This shows the socioeconomic importance of tourism in the general economic context of the Serra da Bodoquena.

\section{ANALYSIS OF ECOLOGICAL SUSTAINABILITY OF SPELEOTOURISM IN THE SERRA DA BODOQUENA}

Field work in the Serra da Bodoquena has shown that tourism in the area cannot exactly be considered ecotourism nor sustainable tourism if one observes, on the one hand, the concept of ecotourism publicized by the Brazilian Institute for Tourism (EMBRATUR) (Brasil 1994), which reproduces the main tendencies identified by Fennell (2001), and, on the other, that of sustainability if one considers that the tourists to the region consider nature only as an attraction, rather than being concerned with its conservation (Lobo et al. 2007; Souza \& Lobo 2007). Tourism is practiced in a nature which is extremely fragile, as proved by the analyses of Sabino and Andrade (2003); this is in agreement with the observations of Swarbrooke (2002).

The principles of sustainable management of caves made explicit in studies such as that of Cigna and Forti (1988), Marra (2001), Scaleante (2003) and Lobo (2006a) point out the need for the following interventions: previous studies of the environment, a means of identifying points of fragility, delimitation of specific zones for exploitation, environmental zoning in caves, indication of guidelines for preservation and behavior of guides and tourists, establishment of a carrying capacity based on technical-scientific studies, and the installation of an adequate infrastructure for visitation to reduce negative impacts and maintain environmental damage at a minimum. In most cases, these points have not been contemplated in the official management plans, nor are they implemented for daily visitation procedures.

The analysis of the work of researchers in the area of speleotourism indicates that the management plan can diminish negative impacts on the environment. However, there are limits to planning, especially since the techniques available are limited. For speleotourism, the procedures for management lack adaptations specific to caves. The spatial confinement of natural cavities limits the application of the traditional technical approach. Most of the methods in use give priority to the existence of alternatives rather than the direct reduction in the direct impacts generated by tourism, because these are generally spread out over wider areas of space and/ or time. Moreover, the quantitative methodologies valued by local planners, such as the Carrying Capacity of Miguel Cifuentes (Cifuentes-Arias et al. 1999), also face problems in applicability given the great difficulty of quantifying the necessary parameters.

Practical examples of the use of tourist carrying capacity can be found in the Serra da Bodoquena, starting with the Anhumas pit. The number of visitors has been determined as a function of the time which the activity takes to complete - descending a rope to a depth of 72 $\mathrm{m}$, snorkeling and/or diving in the lake at the bottom of the pit, and ascending again to the surface. Although the difficulty of the program sets strict limits on visitation, no studies have demonstrated whether the actual environment of the pit can withstand them.

The unique conditions of the Anhumas pit makes the use of traditional methods complicated. No alternative routes for visitation are possible, since tourists must enter and exit from the same place; moreover, the need for the use of ropes makes visitation more complicated. Furthermore, the Carrying Capacity of Cifuentes cannot be applied, since there is no linear path inside the pit. Some other means is needed to establish the operational capacity of the attraction.

Despite being recognized as one of the least efficient means of controlling visitation and preserving the environment (Swarbrooke 2000) since it is vulnerable to 
market needs, the Carrying Capacity of Cifuentes may actually be more efficient for tourist-environmental management of some attractions, even though ecological carrying capacity would normally be preferred because it considers environmental limits. This leads to an interesting paradox between theory and management practices, which demonstrates the inefficiency of the development of pre-conceived models for planning and management.

The Sao Miguel cave also adopts a system for the control of visitation which considers mainly operational capacity, with the total number of tourists permitted per day calculated exclusively as a function of the time required for visitation and the size of groups allowed. The number of visits varies as a function of the season of the year: 285 people in the summer and 255 in the winter. The difference, quite small considering that many more tourists travel in Brazil during the summer, is actually due to the reduced number of daylight hours during the winter. With little light, the external part of the trip becomes less attractive for the contemplation of nature. Moreover, the number of visitors at any one time is actually limited to 10 individuals, although the present Management Plan permits up to 15 . This reduction was designed to minimize the impact of this visitation, as well as maximizing the experience and safety of the tourists. This proves the relativity of the definition of capacity.

On the other hand, the excess in detail reported in many technical studies may lead to unfeasible recommendations. Too many limitations in relation to visitation may make tourism unfeasible or too selective. One example is that of the Anhumas pit. The Management Plan fixes a maximum of 18 visits per day, but this increases the per capita costs of the operation of the attraction, drastically limiting even this visitation, especially for those with limited financial means. The technical limits imposed to conserve the speleological heritage also consider market needs, especially when involving areas of private ownership and the need to make a profit.

But the techniques available can be useful in the conservation of nature if no pressures from the market are allowed to intrude. Moreover, the recommendations should be analyzed carefully in relation to imposed limitations and the potential of an attraction. Some proposals may be valid in relation to the potential benefits. For the natural cavities of the Serra da Bodoquena, the consideration of a series of small contributions may provide help in the development of a speleotourism which is able to approximate the most sustainable ideal for the use of the speleological heritage.

The first of these considerations involves the intrinsic limitations of usage due to the techniques required for exploration. This is the case of caves where difficult access provides a natural limit to visitation. It is possible to maintain the economic feasibility of the activity while simultaneously inhibiting mass visitation. This includes those caves which require the use of rapelling and/or diving techniques, such as the Anhumas pit. The second consideration involves caves where visitation requires no special precautions for exploration. This makes a larger volume of daily visits possible. Yet if no behavioral limits are enforced for such a large number of visitors, environmental degradation is almost certain, and probably irreversible.

The first recommendation, based on the studies cited in the methodology of this article, is that restrictions be based on the reality of nature rather than on operational parameters for the control of the number of visits permitted daily for each of the attractions. Farrell and Marion (2002) have studied the advantages and disadvantages of the use of carrying capacity in the management of tourism in natural areas, and they have shown that too much emphasis on the number of visitors often ignores behavioral issues, as well as the question of access and impact.

McCool and Lime (2001) also criticize the use of carrying capacity to limit tourism, emphasizing that the conditions necessary for its use are rarely found in real situations. The result is often limitation as a function of operational capacity. For caves, given the natural limitations imposed by the environment, especially spatial restrictions, the methodology seems useful. However, the method utilized must make it possible to combine qualitative aspects with those of an operational nature so that the actual limits imposed by environmental fragility will not be overlooked. Even if the establishment of a number of visitations is the point of departure, this recommendation should be accompanied by constant monitoring to improve future decision in relation to new proposals for management. This emphasizes the importance of the "good sense" of the stakeholders for cave management. The numerical correlation between visitation and environmental alteration, even based on measurable environmental parameters, cannot easily be identified, although this cannot free managers from the responsibility of looking for ways to avoid the impacts of speleotourism.

Moreover the problems which emerge reflect the problems of the method used. The quantitative calculation of carrying capacity requires review, at least as it is traditionally conducted, since it mixes environmental and anthropic aspects in a single step. This makes it difficult, if not impossible, to separate the resilience of the environment to tourism from human limitations.

The Lago Azul cave is an interesting example. The original studies used to calculate the number of visitors to the cave recommended that this be based on microcli- 
matic monitoring, as recommended by Cigna and Forti (1988) and Cigna (2002). However, a year of daily monitoring of the temperature and relative humidity of the air inside the cave proved that it reflects external climatic variations on the same scale, and a decision was made to adopt the parameter of carrying capacity. The final calculations thus considered only certain anthropocentric features, such as difficulty of access and slippery paths, ignoring the fact that the main objective of the adoption of a management plan is to identify environmental fragilities so that the number of visitors can be reduced to preserve the natural environment from damages caused by the presence of people. In the Lago Azul cave, there is an explicit limit for the number of visitors, but it is unknown whether this reflects the true fragility of the cave environment or not, since only aspects of the physical access of people were actually considered. The present Management Plan permits 330 visitors per day (Boggiani et al. 2007a), with actual visitation ranging in the neighborhood of 305; this limit, however, was determined by the use of the method of Cifuentes (Cifuentes-Arias et al. 1999), without any actual consideration of environmental fragility.

Another thing which should be modified is the process used to calculate carrying capacity. Initially, the socalled physical carrying capacity (CCF) is calculated, as a function of time and space available. The next step is the calculation of the real carrying capacity (CCR), obtained by the application of correction factors (FCs) to modify the initial value. These corrective factors institute a percentage of the CCR as the recommended carrying capacity, established on the basis of problems of either an environmental nature or based on human difficulties (Cifuentes-Arias et al. 1999). As firstly proposed, the method leads to the mixing of the two different kinds of problems, thus making it impossible to separate one from the other in the final analysis. What prevails is a generalized sum of factors which may overly restrict public use. Working with values well below those actually "possible" leads to under-visitation of the attraction, which could result in increased prices and greater pressure to open more attractions to deal with the demand. Another problem is that none of the attractions researched has instituted a plan of continuous monitoring, although this would permit constant review of the limits for visitation stipulated. The lack of the monitoring of impact on the caves studied perpetuates a common error in the management of ecotourism in Brazil. In general, the few studies conducted focus on the planning of an activity without the projection of continuous monitoring. Collusion of licensing organs and the costs involved are the main factors contributing to this situation.

This is problematic, not only in relation to ecological sustainability, but also to increased economic and even social gains which might be possible without sacrificing ecological considerations. This latter perspective differs from that of sustainability; the former focuses only on the most parsimonious utilization of natural resources in order to promote their continued conservation, while the latter would make increased opportunities for socioeconomic sustenance feasible in the region involved. Often too many precautions can be excessively limiting, since tourism may be less damaging to the environment than other anthropic activities. However, for caves, the environment is extremely fragile and stable, thus requiring even greater care to be able to continue to offer the attraction for a long time period.

However, tourism in the Serra da Bodoquena does not recognize that speleotourism requires a special type of planning and management. Speleotourist routes are treated just like any other attraction involving nature, and the unique aspects are not taken into consideration. What is practiced is a standardization of procedures and techniques which are perpetuated in a manner which will improve the "quality" of what is perceived to be a global tourist product. The techniques, as they are used and applied, reinforce the perspective of a single ideal model, and no proposals for visitation contemplate qualitative nuances of the relation of tourists to the environment.

\section{CONCLUSIONS}

The studies realized here have shown that it is necessary to improve the methods, techniques and management systems for tourism in natural cavities in Brazil. In general, it was seen that the methods utilized were derived from the management of other protected natural areas and trails, perpetuating policies which have often been phased out in other parts of the world. The carrying ca- pacity for visitation is still widely used as the main method for the control of the flow of visitors, and it is based on stipulated limits which, in most cases, have been the limits for visitation adopted. The Lago Azul cave, where microclimatic studies were conducted to furnish more precise parameters for management, is an exception (Boggiani et al. 2007a). However, for none of the four 
cases analyzed has a program for continuous management of impact from tourist visitation been adopted.

It is thus concluded that the main practical objective of carrying capacity adopted in the Serra da Bodoquena is the facility which it provides for the stakeholders to control the flow of visitation, which is guaranteed by the use of a unified system of vouchers in Bonito.

It should be pointed out, however, that various studies (e.g. Hoyos et al. 1998; Boggiani et al. 2007a; Lobo 2008) have demonstrated the possibility of applying more up-to-date techniques to improve the system of management. The natural cavities in the Serra da Bodoquena are among those where there is a well-developed system of control, better than that found in many other speleotourist attractions in Brazil, but it is only relatively positive, since the criterion adopted is not the quality of the practices adopted in the region, but rather a reflection of the lack of adequate management found in the country.

Since the space in caves is limited, speleotourism must move beyond the basic issues of carrying capacity to provide management. In caves, there is much less chance to use dispersion as a means for mitigating environmental impacts than is feasible for activities conducted in the open air. The question is a technical one, but a solution is essential for the survival of the tourism based on the fragile karst landscape as its primary attraction. However, the procedures of carrying capacity can be used as a starting point for the management of caves, as long as they are adequately monitored so that more appropriate limits can be established, based on the actual response of the environment to anthropic impact.

Speleotourism in the Serra da Bodoquena can definitely be improved in relation to ecologic and management issues and it should be able to become an example for the use of caves for local and national tourism, whether in relation to practices or the formulation of adequate public and management policies. This should reveal possibilities which have not yet been explored, whether in relation to awareness, education, or environmental conservation, breaking with more conventional forms of tourism in nature and increasing the possibilities of thinking about the ways in which what we call nature can be used.

\section{ACKNOWLEDGEMENTS}

Thanks to Linda Gentry El-Dash and the Brazilian Speleological Society for assistance into translate the article into English and to the reviewers of Acta Carstologica, especially Ms. Mélanie Duval, for her fundamental contributions made to the original version of this article.

\section{REFERENCES}

Barbosa, M.A.C. \& R.A. Zamboni, 2000: Formação de um cluster em torno do turismo de natureza sustentável em Bonito - MS.- MPOG/IPEA, pp. 46, Brasília.

Barroco Neto, J.L., 2009: Mapeamento subaquático para planos de manejo em cavernas alagadas.- In: Brazilian Society of Speleology (ed.) Proceedings of the $30^{\text {th }}$ Congresso Brasileiro de Espeleologia, July 2009, Montes Claros, Minas Gerais. SBE, 7-10, Montes Claros.

Boggiani, P.C., 2001: Ciência, meio ambiente e turismo em Bonito: A combinação que deu certo?- In: Banducci Júnior, A. \& E.C. Moretti (orgs.). Qual paraíso? Turismo e ambiente em Bonito e no Pantanal. Chronos/UFMS, pp. 151-168, São Paulo.
Boggiani, P.C., da Silva, O.J., Gesicki, A.L.D., Gallati, E.A.B., Salles, L. de O. \& M.M.E.R. Lima, 2007a: Definição de capacidade de carga turística das cavernas do monumento natural gruta do Lago Azul (Bonito,MS).- Geociências, 26, 4, 333-348.

Boggiani, P.C, Sallun Filho, W., Karmann, I., Gesicki, A.L., Philadelphi, N.M. \& M. Philadelphi, 2007b: Lago Azul cave, Bonito, State of Mato Grosso do Sul - Where the sunshine turns blue.- In: Winge, M., Schobbenhaus, C., Souza, C.G.R., Fernandes, A.C.S., Berbert-Born, M. \& E.T. Queiroz (eds.). Geological and paleontological sites of Brazil.- SIGEP, pp. 1-11, Brasília.

Brasil., 1994: Diretrizes para uma política nacional de ecoturismo.- EMBRATUR, pp. 48, Brasília. 
Camargo, R.R. \& M.L.F. Lourenção, 2007: Levantamento espeleológico da Serra da Bodoquena.- In: Brazilian Society of Speleology (ed.) Proceedings of the $29^{\text {th }}$ Congresso Brasileiro de Espeleologia, July 2007, Ouro Preto. SEE/SBE, 1-7, Ouro Preto.

Cifuentes-Arias, M., Mesquita, C.A.B., Méndez, J., Morales, M.E., Aguilar, N., Cancino, D., Gallo, M., Ramirez, C., Ribeiro, N., Sandoval, E. \& M. Turcios, 1999: Capacidad de carga turística de las áreas de uso público del Monumento Nacional Guayabo, Costa Rica.- CATIE/WWF, pp. 99, Turrialba.

Cigna, A.A., 2002: Monitoring of caves: conclusions and recommendations.- Acta Carsologica, 31, 1, 175177.

Cigna, A.A. \& P. Forti, 1988: The environmental impact assessment of a tourist cave.- In: Kranjc, A. (ed.) Cave Tourism International Symposium at-170 Anniversary of Postojnska Jama, Postojna (Yugoslavia), UIS, 29-38, Postojna.

Cigna, A.A. \& E. Burri, 2000: Development, management and economy of show caves.- International Journal of Speleology, 29, 1, 01-27.

Doorne, S., 2000: Caves, culture and crowds: carrying capacity meets consumer sovereignty.- Journal of Sustainable Tourism, 8, 2, 116-130.

Farrell, T.A. \& J.L. Marion, 2002: The protected area visitor management (PAVIM) framework: a simplified process for making management decisions.- Journal of Sustainable Tourism, 10, 1, 31-51.

Fennell, D.A., 2001: A content analysis of ecotourism definitions.- Current Issues in Tourism, 4, 5, 403421.

Figueiredo, L.A.V., 1998: Cavernas brasileiras e seu potencial ecoturístico: Um panorama entre a escuridão e as luzes. In: Vasconcelos, F.P. (org.) Turismo e meio ambiente. UECE, pp. 1-22, Fortaleza.

Gnaspini, P., Trajano, E. \& L.E. Sánchez, 1994: Província espeleológica da Serra da Bodoquena, MS: exploração, topografia e biologia.- Espeleo-tema, 17, 19-42.

Grechi, D.C., Lobo, H.A.S., Lunas, J.R.S. \& P.C.S. Martins, 2009: Autogestão no controle de visitantes: O voucher unificado de Bonito-MS.- In: Phillippi Jr., A. \& D.V.M. Ruschmann (eds.) Meio ambiente $e$ sustentabilidade no turismo. Manole, pp. 913-933, Barueri.

Hamilton-Smith, E., 2007: Karst and world heritage status.- Acta Carsologica, 36, 291-302.
Hoyos, M., Soler, V., Cañaveras, J.C., Sánchez-Moral, S. \& E. Sanz-Rubio, 1998: Microclimatic characterization of a karstic cave: Human impact on microenvironmental parameters of a prehistoric rock art cave (Candamo Cave, Northern Spain).- Environmental Geology, 33, 4, 231-242.

Labegalini, J.A., 1996: Levantamento dos impactos das atividades antrópicas em regiões cársticas - estudo de caso: Proposta de mínimo impacto para implantação de infra-estrutura turística na Gruta Lago Azul - Serra da Bodoquena (Município de Bonito, MS).Master dissertation, Sao Paulo University, pp. 185.

Lino, C.F., Boggiani, P.C., Cortesão, J., Godoy, N.M. \& I. Karmann, 1984: Projeto grutas de Bonito (MS): Diretrizes para um plano de manejo turístico.- MSTUR/SPHAN/FNPM, pp. 212, São Paulo.

Lobo, H.A.S., 2006a: Caracterização dos impactos ambientais negativos do espeleoturismo e suas possibilidades de manejo.- In: Rejowski, M., Santos, R. $\&$ M. Barreto (eds.) Proceedings of $4^{\text {th }}$ Seminário de Pesquisa em Turismo do Mercosul, June 2006, Caxias do Sul. UCS, 1-15, Caxias do Sul.

Lobo, H.A.S., 2006b: O lado escuro do paraíso: Espeleoturismo na Serra da Bodoquena.- Master dissertation, Mato Grosso do Sul Federal University, pp. 164.

Lobo, H.A.S., 2007: Método para avaliação do potencial espeleoturístico do Parque Nacional da Serra da Bodoquena, MS.- Caderno Virtual de Turismo, 7, 3, 99-110.

Lobo, H.A.S., 2008: Capacidade de carga real (CCR) da caverna de Santana, Parque Estadual Turístico do Alto Ribeira (PETAR) - SP, e indicações para o seu manejo turístico.- Geociências, 27, 3, 369-385.

Lobo, H.A.S., Pereira, C.H. \& J.B. Almeida, 2007: Patrimônio para quem? Os turistas que visitam a Gruta do Lago Azul - Bonito, MS.- In: Seabra, G., Barbosa, J.M., Neu, C. \& I.T. Mendonça (eds.) Proceedings of $10^{\text {th }}$ Encontro Nacional de Turismo em Base Local, October 2007, João Pessoa. ENTBL, 1361-1369, João Pessoa.

Lobo, H.A.S., Perinotto, J.A. de J. \& P.C. Boggiani, 2008: Espeleoturismo no Brasil: Panorama geral e perspectivas de sustentabilidade.- Revista Brasileira de Ecoturismo, 1, 1, 62-83.

Lomba, G., 2004: Revelando o invisível: O mundo do trabalho na atividade turística em Bonito, MS.- Master dissertation, Mato Grosso do Sul Federal University, pp. 152.

Lunas, J.R.S., 2000: Turismo sustentável: Descrição e avaliação da gestão do turismo de Bonito-MS.- Master dissertation, Brasília University, pp. 201. 
Lunas, J.R.S., 2006: Ecoturismo sociedade anônima: Sustentabilidade, dilemas e perspectivas do turismo na Serra da Bodoquena - MS.- Doctoral thesis, Brasília University, pp. 309.

Marra, R.J.C., 2001: Espeleo turismo: planejamento e manejo de cavernas.- WD Ambiental, pp. 224, Brasília.

Mato Grosso do Sul (State)., 2001: Decreto $n^{\circ} 10.394$ de 11 de junho de 2001.- Governo do Estado de Mato Grosso do Sul.

McCool, S.F. \& D.W. Lime, 2001: Tourism carrying capacity: tempting fantasy or useful reality?- Journal of Sustainable Tourism, 9, 5, 372-388.

Ribeiro, R., 1996: Bonito demais.- Os caminhos da Terra, $49,5,10-21$.

Sabino, J. \& L.P. de Andrade, 2003: Uso e conservação da ictiofauna no ecoturismo da região de Bonito, Mato Grosso do Sul: O mito da sustentabilidade ecológica no rio Baía Bonita (Aquário Natural de Bonito).Biota neotropica, 3, 2, 1-9.

Scaleante, J.A.B., 2003: Avaliação do impacto de atividades turísticas em cavernas.- Master dissertation, Campinas University, pp. 82.
Souza, H.A.S. \& H.A.S. Lobo, 2007: Análise da percepção ambiental dos turistas na RPPN Fazenda São Geraldo (Rio Sucuri) - Bonito, MS.- In: Pereira, A.E. (ed.) Proceedings of $9^{\text {th }}$ Seminário Internacional de Turismo, November 2007, Curitiba. Unicemp, 117, Curitiba.

Swarbrooke, J., 2000: Turismo sustentável: gestão e marketing.- Aleph, pp. 140, São Paulo.

Swarbrooke, J., 2002: Turismo sustentável: conceitos e impacto ambiental.- Aleph, pp. 140, São Paulo.

Vargas, I.A., 2001: A gênese do turismo em Bonito. In: Banducci Júnior, A. \& E.C. Moretti (orgs.). Qual paraíso? Turismo e ambiente em Bonito e no Pantanal.- Chronos/UFMS, pp. 127-150, São Paulo.

Veríssimo, C.U.V., Ricardo, J.M., Barcelos, A.C., Nogueira Neto, J.A., Silva Filho, W.F., Nacimento Júnior, J.V. \& A.O. Paiva, 2005: Espeleoturismo e microclima da gruta de Ubajara, CE.- Estudos Geológicos, $15,244-53$. 